C 2021 by the author. This work is licensed under

Creative Commons Attribution 4.0 International License

https://creativecommons.org/licenses/by/4.0/

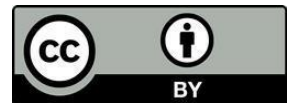

elSSN: $2708-9800$

https://doi.org/10.47316/cajmhe.2021.2.4.02

CLINICAL MEDICINE

HYPOTHESIS

\title{
NOT JUST CALORIC RESTRICTION: A COMPLEX APPROACH TO PROLONG LIFESPAN AND IMPROVE QUALITY OF LIFE
}

Received: October 28,2021

Accepted: December 6, 2021

Galina V. Morgunova ${ }^{1 *}$ http://orcid.org/0000-0002-5259-0861

${ }^{1}$ Evolutionary Cytogerontology Sector, School of Biology, Lomonosov Moscow State University, Moscow, Russian Federation

\section{${ }^{*}$ Corresponding author:}

Galina V. Morgunova, Ph.D., Evolutionary Cytogerontology Sector, School of Biology,

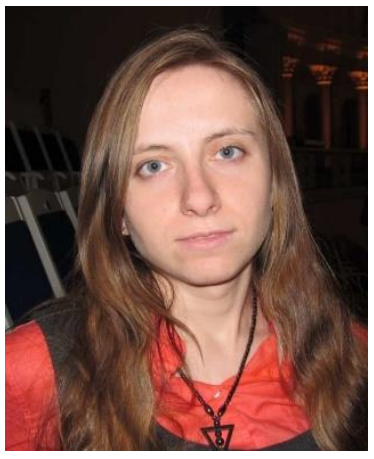
Lomonosov Moscow State University, 1-12 Leninskie Gory, Moscow, 119234, Russian Federation;

Twitter handle: @GalinaMorgunova; E-mail: morgunova@mail.bio.msu.ru

\begin{abstract}
Aging is an urgent healthcare issue in view of the rapid growth of the proportion of older persons. Searching for reliable aging biomarkers and prolonging lifespan are increasingly important scientific directions. Experimental gerontology helps to explore fundamental facts which are not always applicable in clinical scenarios. As an example, caloric restriction is one of the key interventions that prolongs laboratory animals' lifespan and ameliorates some, but not all, aging biomarkers in humans. Consequences of overeating such as obesity, insulin resistance, type 2 diabetes, and metabolic syndrome are taking their toll with aging, making caloric restriction a hot topic in gerontology and geriatrics. Nevertheless, caloric restriction is not widely applicable in view of poor adherence to and limitations of strict diets. Drugs mimicking caloric restrictions, the so-called caloric restriction mimetics, are developed to overcome these limitations. Caloric restriction alone is not a panacea since metabolic pathways are complex and not responsive to a single intervention. Fasting and exercising are additional options for reducing effects of excessive intake of calories. Arguably, physical activity significantly improves the quality of life at old age and delays the onset of overt insulin resistance and associated diseases. Thus, developing optimal fasting and exercising schemes is becoming increasingly important. Such interventions are confounded by a number of factors, including circadian and other biorhythms and baseline metabolic activity. It is justifiable to test fasting and exercising in experimental animals to reveal numerous confounding factors. A hypothesis in this article points to the role of complex interventions such as moderate and balanced diet, intermittent fasting, and physical exercise adjusted to circadian rhythms for prolonging life and improving quality of life. The hypothesis may shed light on fundamental mechanisms of aging and perspectives of anti-aging drug therapies.
\end{abstract}

Keywords: Aging, Caloric restriction, Lifespan, Longevity, Insulin resistance, Diabetes, Fasting, Circadian rhythm, Physical exercise

How to cite: Morgunova GV. Not just caloric restriction: a complex approach to prolong lifespan and improve quality of life. Cent Asian J Med Hypotheses Ethics 2021:2(4):190-197. https://doi.org/10.47316/cajmhe.2021.2.4.02

\section{INTRODUCTION}

Proportion of elderly people is constantly increasing, raising global concerns over the age-related diseases and old-age quality of life [1]. Aging disorders often involve multiple organ systems and manifest, for example, with insulin resistance, underlying obesity, type 2 diabetes, and metabolic syndrome [2, 3]. Obesity is a global issue affecting all age groups. According to the World Health Organization, more than $650 \mathrm{mln} 18+$ 
adults were obese in 2016 (https://www.who.int/newsroom/fact-sheets/detail/obesity-and-overweight).

Caloric restriction is viewed as the most effective experimental intervention to prolong lifespan $[4,5]$. Numerous hypotheses are proposed to explore the effects of caloric restriction on insulin resistance, obesity, and type 2 diabetes. Although some molecular mechanisms of the beneficial effects are widely known, related clinical studies often result in contradictory conclusions.

Signaling molecules associated with metabolism and proliferation such as insulin, insulin-like growth factor-1 (IGF-1) [6], and target of rapamycin (TOR) complex [7] play an important role in the development of age-related disorders. Both mitogenic and metabolic effects of these pathways influence aging mechanisms. Positive antiaging interventions include increasing insulin sensitivity (e.g., Klotho activation), suppressing TOR (rapamycin), and IGF-1 (gene knockout) [5]. A critical role is also played by AMP-activated protein kinase (AMPK), predominantly antagonizing the effects of TOR and activating catabolic reactions (e.g., lipolysis, glycolysis).

Metabolic pathways are explored using a variety of model objects. Genetic and pharmacological interventions are known to prolong lifespan of various organisms, from unicellular yeast to primates. However, it is unclear whether caloric restriction can prolong the lifespan of humans. By singling out metabolic cascades, researchers often overlook the complexity of aging mechanisms.

Caloric restriction decreases basal metabolic rate [8]. It was previously believed that such decrease helps to prolong the average and maximum life span of laboratory animals [9]. However, the relationship between metabolism and lifespan is complex and not entirely understood. Physical activity increases the metabolic rate [10]. In long-lived insulin/IGF-1 mutant fruit flies, metabolism is not reduced [11]. Human subjects on longterm strict diet end up with slow metabolism, rapidly gaining weight after discontinuing the diet [12]. Previously, some studies have suggested declining basal metabolism from age of 15 [13]. Latest studies, however, indicated that the noticeable decline starts at 60 [14]. After 60, age-related disorders manifest clinically. In this regard, diet-induced slow basal metabolic rate may accelerate age-related diseases. Since high metabolic rate is associated with mortality risk in humans [15], optimal metabolic rate can be established to prevent age-related diseases.
There is also an argument related to the influence of caloric restriction on cell proliferation. Some researchers consider caloric restriction as a means of suppressing cell proliferation and reducing cancer risk [16]. Rapamycin, or sirolimus, a widely used anti-aging macrolide compound that inhibits the TOR complex, also suppresses cell proliferation and treats some tumors [17]. Nonetheless, cell proliferation is intimately involved in normal functioning of some organ systems such as musculoskeletal system. Muscle loss and atrophy lead to the enhanced course of type 2 diabetes and metabolic syndrome [18]. The TOR complex inhibition and AMPK activation can also lead to muscle loss. Hyperactivation of this kinase precedes Alzheimer's disease [19], while its baseline activity may prevent the deposition of abnormal tau protein in the brain and fight dementia. Catabolic processes such as autophagy complement cell-proliferation signaling pathways and induce muscle growth [20]. In this regard, intermittent fasting may regulate calorie intake and balance catabolic and anabolic processes.

The effect of intermittent fasting on aging biomarkers and lifespan is extensively explored in animal and human studies of obesity and other metabolic disorders [21]. Intermittent fasting fights obesity and improves cardiovascular functional capacities [22, 23] which can be associated with decreased basal metabolic rate [24]. The effect of intermittent fasting is closely related to circadian rhythms. Night shifts with high level of illumination and excessive use of electronic devices disrupt sleep. Social jetlag increases the risk of type 2 diabetes and metabolic syndrome [25]. Disturbed circadian rhythms in the elderly change the temperature rhythm and melatonin release [26]. Also, the disturbed rhythms predate neurodegenerative, metabolic, inflammatory, and oncological diseases, as well as, in different species, the deviation of the internal circadian rhythm from the real 24-hour one is in a negative relationship with life span [26].

Abnormal circadian rhythms affect eating habits by switching main calorie intake from breakfast and lunch to dinner. At the same time, eating and exercising can help synchronize circadian rhythms. Subjects with a late chronotype can shift their rhythm to an earlier one by morning and evening exercises [25]. Again, intermittent fasting may help a lot provided circadian rhythms are properly considered.

Although most laboratory mammals have nocturnal chronotype, research activities and related manipulations take place during daytime. Feeding of nocturnal rodents in the daytime uncouples the 
peripheral clock from the central clock [27]. In a human study [28], considering experimental studies in mice, intermittent fasting, switched from dawn to sunset, resulted in a decrease of prooncogenes, an increase of antitumor and antidiabetic factors, and improved body mass index and arterial blood pressure.

Experimental studies which are important for understanding mechanisms of caloric restriction are often at odds with clinical studies [29]. For example, genetic and pharmacological interventions may not always be applicable to humans, and in many cases, such use can make worse the quality of life of the elderly. Increased physical activity correlates with lowered risk of type 2 diabetes [30, 31], metabolic syndrome [3], and overall mortality [32]. At the same time, long-term use of rapamycin by young healthy volunteers led to the suppression of anabolic processes in their muscles [29]. Physical exercise helps maintain muscle mass and improves quality of life in older subjects. Importantly, skeletal muscles consume up to $70 \%$ of secreted insulin [33]. Physical activity improves insulin sensitivity [34, 35].

\section{HYPOTHESIS}

A combination of moderate nutrition, intermittent fasting, and physical exercise adjusted to circadian rhythms may help improve the quality of life and prolong lifespan. Caloric restriction and related mimetics cannot replace physical exercise. Moderate eating at regular intervals and at the same daytime may have better effects than prolonged fasting, caloric restriction, and use of caloric restriction mimetics. As a result, the basal metabolic rate should be maintained at a level corresponding to the age of 20-30. Food intake and physical activity should be adjusted to chronotypes. Meal consumptions with 6-8 hour intervals are advisable without snacks in between.

Overeating and drugs suppressing the TOR complex will have conflicting effects. In the case of drugs such as mild uncouplers (protonophores), some of the energy is lost in the form of heat but the potential of such substances as caloric restriction mimetics is not fully understood. Notably, overdosing of the most famous uncoupler 2,4dinitrophenol is fatal [36].

Diets should not just reduce calorie intake; balancing intake of proteins, fats, carbohydrates, and other essential food components are critically important. Paying more attention to physical exercises is also important [37].

\section{HYPOTHESIS EVALUATION}

Examining "maximally healthy" animals is an optimal strategy to explore fundamental mechanisms of aging and search for anti-aging drugs [38]. Outbred lines like Wistar rats are more preferable for research since inbred lines have low viability. Mutant rats and mice are not suitable for anti-aging research.

Long-term experiments with construction of survival curves could be an optimal study design. Such experiments can be labour intensive and expensive, therefore it is permissible to conduct short-term experiments. In this case, starting age of animals (rats) should be 22-24 months (corresponds to 60 years in humans) with at least 3-month intervention and monitoring of aging markers. Subsequent longer-term interventions are desirable in case of initial positive effects. In a long-term experiment, until adulthood, animals should be kept in normal conditions and fed ad libitum, division into groups should take place after reaching maturity.

Before dividing into groups, it is necessary to weigh the animals, measure their temperature, determine the basal metabolic rate by indirect calorimetry with the determination of oxygen uptake and carbon dioxide production. Measuring blood glucose, blood and urine $\mathrm{pH}$, and aging biomarkers should be monitored. Keeping the animals in metabolic cages for 24 hours before the experiment is also advisable.

The following division into groups is proposed: $1-a d$ libitum feeding (control); 2 - caloric restriction; $3-$ ad libitum feeding, rapamycin treatment; 4 - feeding 2-3 times a day, feed is given without limitation in quantity, but for a limited time, for 30-60 minutes (the ideal situation is feeding at night; as an alternative, feeding in the early morning and late evening), it is recommended to keep records of the food eaten; water consumption is always non-limited; 5 - the same diet, with the presence of running wheels. Rapamycin can be replaced with other drugs, for example, biguanides (such as metformin).

Regular weighing of animals and determination of their body temperature is required. The following parameters should be monitored: glucose, insulin (homeostasis model assessment - insulin resistance, HOMA-IR index), total cholesterol, triglycerides, low-density lipoprotein cholesterol, very low-density lipoprotein cholesterol, leptin, ghrelin, and lactate. The ad libitum groups should be deprived from food intake to measure fasting glucose and insulin levels. Quantifying 
inflammatory markers is also important (e.g., TNF-a, IL1, IL-6).

The basal metabolic rate should be measured weekly. A certain number of rats will need to be taken from groups for morphological analysis of the muscle fibers of the fore and hind limbs ( $m$. biceps brachii, $m$. gastrocnemius, $m$. soleus, $m$. quadriceps femoris), as well as for assessing the level of expression of important participants (protein or mRNA) in metabolic cascades associated with caloric restriction, glucose metabolism, autophagy; e.g. glucose-6-phosphatase, IGF-1, AMPK, mTORC1, GLUT-4, IRS-1 (insulin receptor substrate 1), IRS-2, PKB/Akt (protein kinase B), LC3 (microtubule-associated proteins $1 \mathrm{~A} / 1 \mathrm{~B}$ light chain $3 \mathrm{~B}$ ), p62, sirtuins, FOXO (forkhead box 0 ) in muscles.

The circadian activity of genes responsible for circadian rhythms could be also determined. The choice of the method of feeding the animals and the drug to achieve the caloric restriction effect is left to the authors. Rapamycin ( 0.1 or $0.5 \mathrm{mg} / \mathrm{kg}$ of body weight per day) can be used.

2,4-dinitrophenol does not work when mice are kept at 25 degrees Celcius; keeping the temperature at 30 degrees Celcius is advisable [39]. Thus, the experiments proposed above can be repeated in conditions of thermoneutral temperature (when energy is not spent on thermogenesis). Finally, conducting additional experiments with periodic low temperatures is also important.
A series of experiments with animals on high-calorie diet is also interesting. To assess the lifespan of rats kept on regular and high-calorie diets, different experimental designs are required. The most effective fasting regimens can be chosen and adapted to human (volunteer) studies.

\section{ETHICAL IMPLICATIONS}

One of the main implications of the proposed hypothesis is the widespread dissemination of scientifically supported recommendations. Even practically healthy subjects may suffer from inappropriate dietary habits and excessive physical exertion. All such interventions should be evidence-based. Intermittent fasting can be detrimental for subjects with gastrointestinal disorders. When it becomes clear how the energy balance should be kept, it will be necessary to develop appropriate regimens and diets for subjects with health issues. Studies on healthy volunteers should precede largerscale clinical trials.

\section{FUNDING}

This study was performed within the framework of the state assignment of Moscow State University, part 2 (basic research, no. 121032300215-6).

\section{CONFLICTS OF INTEREST}

The author declares that she has no conflict of interest.

\section{DISCLAIMER}

No part of this manuscript is copied from or published elsewhere.

\section{REFERENCES}

1. World Population Ageing 2019: Highlights. New York, USA: Department of Economic and Social Affairs, United Nation; 2019.

2. Petersen MC, Shulman GI. Mechanisms of insulin action and insulin resistance. Physiol Rev 2018;98(4):21332223.

3. Nomura K, Eto M, Ogawa S, Kojima T, lijima K, Nakamura T, Araki A, Ouchi Y, Akishita M. Association between low muscle mass and metabolic syndrome in elderly Japanese women. PloS One 2020;15(12):e0243242.

4. McCay CM, Crowell MF, Maynard LA. The effect of retarded growth upon the length of life span and upon the ultimate body size: one figure. J Nutr 1935;10(1):63-79.

5. Fontana L, Partridge L. Promoting health and longevity through diet: from model organisms to humans. Cell 2015;161(1):106-118.

6. Gubbi S, Quipildor GF, Barzilai N, Huffman DM, Milman S. 40 Years of IGF1: IGF1: the Jekyll and Hyde of the aging brain. J Mol Endocrinol 2018;61(1):T171-T185.

7. Leprivier $\mathrm{G}$, Rotblat $B$. How does mTOR sense glucose starvation? AMPK is the usual suspect. Cell Death Discov 2020;6:27.

8. Redman LM, Smith SR, Burton JH, Martin CK, Il'yasova D, Ravussin E. Metabolic slowing and reduced oxidative damage with sustained caloric restriction support the rate of living and oxidative damage theories of aging. Cell Metab 2018;27(4):805-815. 
9. Ravussin E, Redman LM, Rochon J, Das SK, Fontana L, Kraus WE, Romashkan S, Williamson DA, Meydani SN, Villareal DT, Smith SR. A 2-year randomized controlled trial of human caloric restriction: feasibility and effects on predictors of health span and longevity. J Gerontol A Biol Sci 2015;70(9):1097-1104.

10. Soultoukis GA, Partridge L. Dietary protein, metabolism, and aging. Annu Rev Biochem 2016;85:5-34.

11. Hulbert AJ, Pamplona R, Buffenstein R, Buttemer WA. Life and death: metabolic rate, membrane composition, and life span of animals. Physiol Rev 2007;87(4):1175-1213.

12. Fothergill E, Guo J, Howard L, Kerns JC, Knuth ND, Brychta R, Chen KY, Skarulis MC, Walter M, Walter PJ, Hall KD. Persistent metabolic adaptation 6 years after "The Biggest Loser" competition. Obesity 2016;24(8):16121619.

13. Henry CJ. Mechanisms of changes in basal metabolism during ageing. Eur J Clin Nutr 2000;54(3):S77-S91.

14. Pontzer H, Yamada Y, Sagayama H, Ainslie PN, Andersen LF, Anderson LJ, Arab L, Baddou I, Bedu-Addo K, Blaak EE, Blanc S. Daily energy expenditure through the human life course. Science 2021;373(6556):808-812.

15. Ruggiero C, Metter EJ, Melenovsky V, Cherubini A, Najjar SS, Ble A, Senin U, Longo DL, Ferrucci L. High basal metabolic rate is a risk factor for mortality: the Baltimore Longitudinal Study of Aging. J Gerontol A Biol Sci Med Sci 2008;63(7):698-706.

16. Neff F, Flores-Dominguez D, Ryan DP, Horsch M, Schröder S, Adler T, Afonso LC, Aguilar-Pimentel JA, Becker L, Garrett L, Hans W. Rapamycin extends murine lifespan but has limited effects on aging. J Clin Investig 2013;123(8):3272-3291.

17. Bjornsti MA, Houghton PJ. The TOR pathway: a target for cancer therapy. Nat Rev Cancer 2004;4(5):335-348.

18. Srikanthan $P$, Karlamangla AS. Relative muscle mass is inversely associated with insulin resistance and prediabetes. Findings from the third National Health and Nutrition Examination Survey. J Clin Endocrinol Metab 2011;96(9):2898-28903.

19. Vingtdeux V, Davies P, Dickson DW, Marambaud P. AMPK is abnormally activated in tangle-and pre-tanglebearing neurons in Alzheimer's disease and other tauopathies. Acta Neuropathol 2011;121(3):337-349.

20. Campanario S, Ramírez-Pardo I, Hong X, Isern J, Muñoz-Cánoves P. Assessing autophagy in muscle stem cells. Front Cell and Dev Biol 2021;8:1917.

21. Longo VD, Di Tano M, Mattson MP, Guidi N. Intermittent and periodic fasting, longevity and disease. Nat Aging 2021;1(1):47-59.

22. Ganesan $\mathrm{K}$, Habboush $\mathrm{Y}$, Sultan S. Intermittent fasting: the choice for a healthier lifestyle. Cureus 2018;10(7):e2947.

23. Zuo L, He F, Tinsley GM, Pannell BK, Ward E, Arciero PJ. Comparison of high-protein, intermittent fasting lowcalorie diet and heart healthy diet for vascular health of the obese. Front Physiol 2016;7:350.

24. Coutinho SR, Halset EH, Gåsbakk S, Rehfeld JF, Kulseng B, Truby H, Martins C. Compensatory mechanisms activated with intermittent energy restriction: a randomized control trial. Clin Nutr 2018;37(3):815-823.

25. Thomas JM, Kern PA, Bush HM, McQuerry KJ, Black WS, Clasey JL, Pendergast JS. Circadian rhythm phase shifts caused by timed exercise vary with chronotype. JCI Insight 2020;5(3):e134270.

26. Hood S, Amir S. The aging clock: circadian rhythms and later life. J Clin Investig 2017;127(2):437-446.

27. Dibner $C$, Schibler U, Albrecht U. The mammalian circadian timing system: organization and coordination of central and peripheral clocks. Annu Rev Physiol 2010;72:517-549.

28. Mindikoglu AL, Abdulsada MM, Jain A, Jalal PK, Devaraj S, Wilhelm ZR, Opekun AR, Jung SY. Intermittent fasting from dawn to sunset for four consecutive weeks induces anticancer serum proteome response and improves metabolic syndrome. Sci Rep 2020;10(1):18341.

29. McLeod M, Breen L, Hamilton DL, Philp A. Live strong and prosper: the importance of skeletal muscle strength for healthy ageing. Biogerontology 2016;17(3):497-510.

30. Srikanthan P, Hevener AL, Karlamangla AS. Sarcopenia exacerbates obesity-associated insulin resistance and dysglycemia: findings from the National Health and Nutrition Examination Survey III. PloS One 2010;5(5):e10805.

31. InterAct Consortium. Physical activity reduces the risk of incident type 2 diabetes in general and in abdominally lean and obese men and women: the EPIC-InterAct Study. Diabetologia 2012;55:1944-1952.

32. Kraschnewski JL, Sciamanna CN, Poger JM, Rovniak LS, Lehman EB, Cooper AB, Ballentine NH, Ciccolo JT. Is strength training associated with mortality benefits? A 15 year cohort study of US older adults. Prev Med 2016;87:121-127.

33. Wilcox G. Insulin and insulin resistance. Clin Biochem Rev 2005;26(2):19-39.

34. Zanuso S, Sacchetti M, Sundberg CJ, Orlando G, Benvenuti P, Balducci S. Exercise in type 2 diabetes: genetic, metabolic and neuromuscular adaptations. A review of the evidence. Br J Sports Med 2017;51(21):1533-1538. 
35. Cartee GD, Hepple RT, Bamman MM, Zierath JR. Exercise promotes healthy aging of skeletal muscle. Cell Metab 2016;23(6):1034-1047.

36. Zack F, Blaas V, Goos C, Rentsch D, Büttner A. Death within 44 days of 2,4-dinitrophenol intake. Int J Legal Med 2016;130(5):1237-1241.

37. Arshavsky IA. Physiological mechanisms and regularities of individual development (Foundations of the negentropic theory of ontogeny). Moscow, Russia: Nauka; 1982.

38. Khokhlov AN, Klebanov AA, Morgunova GV. On choosing control objects in experimental gerontological research. Moscow Univ Biol Sci Bull 2018;73(2):59-62.

39. Goldgof M, Xiao C, Chanturiya T, Jou W, Gavrilova O, Reitman ML. The chemical uncoupler 2,4-dinitrophenol (DNP) protects against diet-induced obesity and improves energy homeostasis in mice at thermoneutrality. J Biol Chem 2014;289(28):19341-19350. 


\section{ТЕК ҚАНА КАЛОРИЯНЫ ШЕКТЕУ ЕМЕС: ӨМІР СУРУ САПАСЫН ҰЗАРТУ МЕН ЖАҚСАРТУДЫҢ КЕШЕНДІ ТӘСІЛІ}

\section{Түйіндеме}

Қартаю - бұл егде жастағы адамдар үлесінің тез өсуіне байланысты денсаулық сақтаудың өзекті мәселесі болып саналады. Қартаюдың сенімді биомаркерлерін іздеу және өмір сүру ұзақтығын арттыру маңызды ғылыми бағыттарға айналуда. Эксперименттік геронтология клиникалық сценарийлерде әрдайым қолданыла бермейтін негізгі фактілерді белгілейді. Мысалы, калорияны шектеу зертханалық жануарлардың өмір сүру ұзақтығын ұзартатын және адамдарда қартаю биомаркерлерінің кейбірін жақсартатын негізгі араласулардың бірі болып табылады. Семіздік, инсулинге резистенттілік, 2 типті қант диабеті және метаболикалық синдром сияқты артық тамақтанудың салдары қартаюға әсер етіп, бұл геронтология мен гериатрияда калориялы тамақтануды шектейді. Алайда, калорияны шектеу қатаң диеталардың нашар сақталуы мен шектеулеріне байланысты кеңінен қолданылмайды. Осы шектеулерді жеңу үшін калорияны шектеу миметикасы деп аталатын калорияны шектеуге еліктеме препараттар әзірленді. Калорияны шектеудің өзі панацея емес, өйткені метаболизм жолдары күрделі және жеке араласуға мүмкіндік бермейді. Ашығ у және жаттығу - бұл шамадан тыс калория қабылдаудың әсерін азайтудың қосымша мүмкіндіктері. Дене белсенділігі егде жаста өмір сүру сапасын едәуір жақсартады және инсулин резистентілікті жә не онымен байланысты аурулардың басталуын бө гейді деп айтуға болады. Осылайша, ашығ у мен жаттығудың оңтайлы схемаларын әзірлеу маңызды тапсырмаларғ а айналуда. Мұндай араласулар бірқатар факторлармен, соның ішінде циркадиялық және басқа биоритмдермен, сондай-ақ бастапқы метаболикалық белсенділікпен күрделенеді. Көптеген ілеспе факторларды анықтау үшін аштық пен жаттығуды тәжірибелік жануарларда өткізген тиімді болып саналады. Бұл мақаладағы гипотеза өмірді ұзарту мен оның сапасын жақсарту үшін бірқалыпты және теңдестірілген диета, үзікті ашығ у және циркадиялық ырғақтарға бейімделген жаттығулар сияқты кешенді араласудың рөлін көрсетеді. Гипотеза қартаюдың іргелі механизмдеріне және қартаюға қарсы дәрідәрмек терапиясының келешегіне әсер етуі мүмкін.

Түйін сөздер: қартаю, тамақ танудың калориялығ ын шектеу, өмір сүру ұзақтығы, ұзақ өмір сүру, инсулин резистенттілігі, қант диабеті, ашығ у, циркадиялық ырғақтар, жаттығулар

Дәйексөз үшін: Моргунова Г.В. Тек қана калорияны шектеу емес: өмір сүру сапасын ұзарту мен жақсартудың кешенді тәсілі. Медициналық гипотеза мен этиканың Орта Азиялық журналы. 2021:2(4):190-197. https:// doi.org/10.47316/ cajmhe.2021.2.4.02

\section{НЕ ТОЛЬКО ОГРАНИЧЕНИЕ КАЛОРИЙНОСТИ ПИТАНИЯ: КОМПЛЕКСНЫЙ ПОДХОД К ПРОДЛЕНИЮ И УЛУЧШЕНИЮ КАЧЕСТВА ЖИЗНИ}

\section{Резюме}

Старение является актуальной проблемой здравоохранения в связи с быстрым ростом доли пожилых людей. Поиск надёжных биомаркеров старения и увеличение продолжительности жизни становятся всё более важными научными направлениями. Экспериментальная геронтология устанавливает фундаментальные факты, которые не всегда применимы в клинических сценариях. Например, ограничение калорийности питания является одним из ключевых вмешательств, которое продлевает продолжительность жизни лабораторных животных и улучшает некоторые, но не все, биомаркеры старения у людей. Последствия переедания, такие как ожирение, инсулинорезистентность, диабет 2 типа и метаболический синдром, сказываются на старении, что делает ограничение калорийности питания популярной темой в геронтологии и гериатрии. Тем не менее, ограничение калорийности питания не имеет широкого применения из-за плохого соблюдения и ограничений строгих диет. Для преодоления этих ограничений разработаны препараты, имитирующие ограничение калорийности питания, так называемые миметики ограничения калорийности. Само по себе ограничение калорийности питания не является панацеей, поскольку метаболические пути сложны и не поддаются единственному вмешательству. Голодание и физические упражнения - дополнительные возможности для уменьшения последствий чрезмерного потребления калорий. Можно утверждать, что физическая активность значительно улучшает качество жизни в пожилом возрасте и задерживает начало явной инсулинорезистентности и связанных с ней заболеваний. Таким образом, разработка оптимальных схем голодания и упражнений становится всё более важной задачей. Такие вмешательства осложняются рядом факторов, включая циркадные и другие биоритмы, а также 
исходную метаболическую активность. Целесообразно испытать голодание и физические упражнения на экспериментальных животных, чтобы выявить многочисленные сопутствующие факторы. Гипотеза в этой статье указывает на роль комплексных вмешательств, таких как умеренная и сбалансированная диета, прерывистое голодание и физические упражнения, адаптированные к циркадным ритмам, для продления жизни и улучшения её качества. Гипотеза может пролить свет на фундаментальные механизмы старения и перспективы медикаментозной терапии против старения. Ключевые слова: старение, ограничение калорийности питания, продолжительность жизни, долголетие, инсулинорезистентность, диабет, голодание, циркадные ритмы, физические упражнения

Для цитирования: Моргунова Г.В. Не только ограничение калорийности питания: комплексный подход к продлению и улучшению качества жизни. Центральноазиатский журнал медицинских гипотез и этики. 2021:2(4):190-197. https://doi.org/10.47316/cajmhe.2021.2.4.02 